\title{
Research on the Training Model Innovation of Compound Talents in Marketing from the Perspective of Digital Economy
}

\author{
Hui Zhang ${ }^{1, *}$ \\ ${ }^{1}$ Shandong University of Finance and Economics, School of Business Administration, Jinan, 250014, China \\ *Corresponding author. Email: jessica880120@163.com
}

\begin{abstract}
Marketing is a highly practical subject. How to carry out teaching reform under the new situation, reshape the training program, and cultivate more compound marketing talents is very important to improve the core competitive advantage of enterprises. Based on the analysis of the current situation and problems in the cultivation of compound marketing talents in universities in China, this paper proposes to reposition the compound talent training goal, reconstruct the curriculum system for compound talent training, innovate the teaching model, strengthen school-enterprise cooperation and cultivate and strengthen the construction of "dual-teacher" faculty team and other countermeasures, in order to provide a theoretical reference for the training model innovation of composite marketing talents in Chinese universities.

Keywords: digital economy; marketing; compound talents; talent training model
\end{abstract}

\section{INTRODUCTION}

With the development of information technology, the widespread application of smart phones has spawned massive amounts of data, and consumer demands have become increasingly personalized and diversified. More and more companies attach great importance to the guiding role of big data in marketing. Companies need to combine online and offline brand building and marketing promotion. As a result, traditional marketing models have undergone disruptive changes, giving birth to a new marketing model-digital marketing[1]. Digital marketing refers to the search and analysis of various related data to fully understand market needs, thereby helping companies change the form of competition. The traditional marketing model of inferring customer needs based on subjective information such as customer lifestyle and value orientation will be transformed into marketing through analysis of various information behaviors and purchase history of customers to meet customer needs.

Enterprises' demand for big data marketing professionals is becoming increasingly urgent. Marketing talents in the context of big data are compound talents that integrate data processing technology and marketing technology[2]. An excellent compound talent must not only be familiar with current internet development trends and have professional network marketing knowledge, but also must have a sufficient understanding of consumers' online buying behavior and psychology, and be able to accurately discover the advertising functions and values various online marketing products. Relevant research shows that most companies in economically developed areas in China are ready to purchase relevant online promotion services. From the feedback of market talents, the demand for big data marketing talents is constantly rising. However, in reality, there is a big gap between the ability of marketing graduates recruited by companies and the expected ability of the company, and there is a shortage of marketing professionals who are suitable for the digital economy era. In the process of marketing professional education and talent training in Chinese colleges and universities, there are more common disadvantages such as "emphasis on theory, teaching, internationality, and despise practice, application, locality and characteristics", as a result, marketing students lack the ability of mastering professional knowledge holistically and systematically[3]. It can be seen that the students trained by the traditional teaching model cannot adapt to the changes in big data marketing methods in the digital economy era, and therefore cannot meet the needs of enterprises for compound marketing talents[4]. According to the survey, $82.3 \%$ of marketing students believe that they are able to master marketing knowledge more proficiently; $78.8 \%$ of students believe that they do not have the ability of data mining, processing and analysis; $47.6 \%$ of students believe that their communication skills need to be promoted; $9.2 \%$ of students believe that they have a certain ability to innovate; only $6.5 \%$ of students indicate that they have an internship experience in a company and have a certain marketing practice ability. It can be seen that there is a big gap between the abilities of marketing students in Chinese colleges and universities and the requirements for compound marketing talents. The performance of various aspects of ability is shown in Figure 1. 


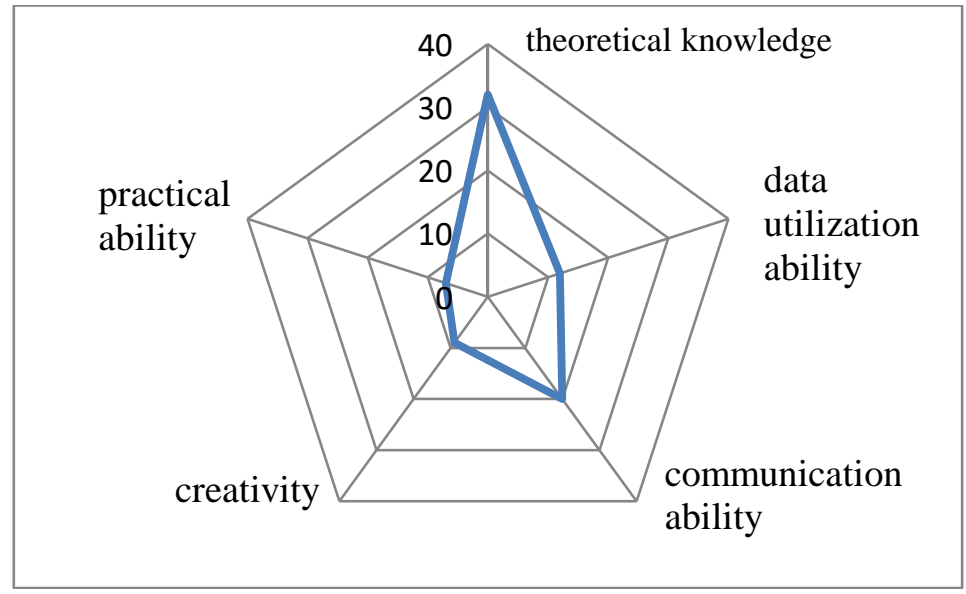

Figure 1. Distribution of the ability of marketing students

To sum up, as Chinese industrial structure enters a period of comprehensive adjustment and upgrading, enterprises have put forward new requirements for talents, which force the reform and innovation of the new business curriculum system[5]. In view of this, how to cultivate compound marketing talents with innovative spirit and practical ability has become a key issue that needs to be solved urgently in the teaching practice of marketing in China. Therefore, it is important to explore and innovate the training model of compound talents in marketing in the digital economy era. This paper intends to analyze the current situation of the cultivation of compound talents in marketing in the digital economy era, find out the main problems in the training of compound talents in marketing in colleges and universities, and clarify the comprehensive qualities and skills that enterprises need for compound marketing talents in the era of digital economy. In the digital economy era, it will discuss in detail the training model of compound talents in marketing majors from the three aspects of talent training target positioning, curriculum system and teaching mode.

\section{ANALYSIS OF THE TRAINING PROBLEMS OF COMPOUND TALENTS IN MARKETING}

\subsection{Inaccurate Positioning of Talent Training Goals}

The traditional training programs of Chinese colleges and universities focus on the teaching and explanation of the theoretical knowledge of marketing students, and they are not fully aware of the changes in the needs of companies for compound marketing talents in the digital economy era. To a certain extent, this has caused colleges to follow the old ways and the training goals for marketing talents which is very inaccurate[6]. Chinese universities carry out relevant teaching activities in accordance with the existing training plan, and it is difficult to cultivate compound marketing talents with high innovation and practical ability to meet the actual needs of enterprises for compound marketing talents.

\subsection{Curriculum System is Relatively Chaotic}

At present, the curriculum system offered by Chinese colleges and universities for marketing students mainly includes core courses such as marketing, consumer behavior, customer relationship management and advertising. The lack of integration and intersection of disciplines makes it difficult to form an effective curriculum system. In addition, college teachers have not thoroughly explored the theoretical knowledge and practical capabilities that corporate marketing students should master in the digital economy era, so it is difficult to reconstruct a scientific and reasonable curriculum system to improve the communication and innovation capabilities and practical ability of marketing students.

\subsection{The Teaching Model is Relatively Outdated}

The marketing professional courses in the digital economy era should take into account the characteristics of innovation and practicality. 
However, the teaching model of Chinese universities is relatively outdated, mainly manifested in backward teaching methods and single assessment methods. Most college teachers choose to instill marketing-related knowledge to students in the form of lectures, and it is difficult to achieve an effective combination of textbook knowledge and practice. In addition, the assessment method of Chinese universities is mainly closed-book examination, which mainly examines the degree of mastery of textbook knowledge by marketing students, and the evaluation effect of skill-based and tool-based courses is relatively poor. Therefore, there is a big deviation between the trained marketing talents and the needs of society.

\subsection{School-Enterprise Cooperation is Not Close Enough}

At present, Chinese universities have fewer off-campus practice bases and platforms, and it is difficult to meet the needs of training compound marketing talents. The cooperation between universities and enterprises in China is not sufficient, and the integration degree between industry and academia is low, which makes it difficult for marketing students to achieve close integration between theoretical knowledge and marketing practice, and improve their communication and practical capabilities.

\subsection{The "Dual Teacher" Faculty is Relatively Weak}

Marketing teachers need to take into account both professional theoretical knowledge and practical experience. However, marketing teachers in colleges and universities in China have not yet reached the "dual-qualified" standard. Although most teachers have rich theoretical knowledge, they lack practical work experience and their own practical ability is weak, so it is difficult to cultivate compound marketing talents.

\section{INNOVATIVE COUNTERMEASURES FOR THE TRAINING MODEL OF COMPOUND TALENTS IN MARKETING MAJORS}

\subsection{Repositioning the Goal of Compound Talent Training}

Colleges and universities should reposition the training goal of compound marketing talents, change the traditional training model of "emphasis on theory and neglect practice", emphasize theory serving practice, improve marketing students' innovative application ability of theoretical knowledge, and clarify the underlying logic of big data marketing and network marketing, and conform to the development trend of the digital economy era. In the era of digital economy, companies are seeking "five-in-one" composite marketing talents with rich theoretical knowledge, strong data processing and analysis capabilities, communication capabilities, innovation capabilities and practical capabilities. Among them, strong data processing and analysis capabilities means that marketing students learn new theoretical knowledge and master data mining, processing and analysis skills to meet the new requirements of enterprises for compound marketing talents in the digital economy era. Therefore, college teachers should discover the shortcomings of marketing students in time in daily teaching, constantly adjust and improve the training goals and strengthen the training of students' data processing and analysis capabilities.

\subsection{Reconstruct the Curriculum System for the Training of Compound Talents}

In the teaching process of college teachers, on the basis of clarifying the qualities and abilities that compound marketing talents need to possess, they should re-construct the curriculum system suitable for compound marketing talents training, such as mixed reform courses. The mixed reform courses are divided into online and offline classes. The online class is mainly for students to independently learn the cutting-edge knowledge of marketing, and to consider the characteristics and changing trends of marketing in the digital economy era, so as to enhance their learning ability and innovation ability. On the one hand, college teachers can incorporate the basic knowledge of big data technology into marketing courses, such as big data network analysis, 
data mining, etc.; on the other hand, college teachers can further enrich the relevant theoretical knowledge of marketing students by supplementing the emerging frontier theories and knowledge of marketing, such as marketing communication, interactive marketing and social media effects in the digital economy era. In addition, college teachers should continue to increase the innovative practice class hours in order to improve the practical and innovative abilities of marketing students. By holding big data marketing practice competitions, college teachers can effectively encourage students to deeply understand the marketing operation process of enterprises in the digital economy era, and then lay the foundation for their own development into composite marketing talents.

\subsection{Innovative Teaching Mode for the Cultivation of Compound Talents}

First of all, college teachers need to optimize teaching methods and conduct modular teaching. The teachers combine case teaching and discussion teaching methods, pay attention to hot search topics and marketing traffic issues, set up reasonable classroom discussion questions, mobilize students' enthusiasm and creativity, and enhance the effect of interactive teaching. Secondly, college teachers should integrate theory with practice, improve students' awareness and participation in marketing activities through on-site simulation, and strengthen students' communication and practical abilities, so as to cultivate the compound marketing talents needed by enterprises. In addition, college teachers strengthen the assessment of the practical ability of marketing students by optimizing the assessment methods, and timely adjust the learning methods and methods of students, and finally a complete assessment system is formed, which encourages students to develop their own innovative and practical abilities on the basis of fully mastering the theoretical knowledge of the course.

\subsection{Strengthen School-Enterprise Joint Training}

In the process of cultivating compound marketing talents, colleges and universities can introduce experts in the field of marketing or invite corporate executives to come to the school to give relevant lectures to enrich students' theoretical knowledge and practical experience. College teachers encourage students to actively participate in off-campus internships or lead students to visit companies to understand the internal operation process of the company and clarify the marketing process of the company, so that the theoretical knowledge obtained can be better applied to the marketing practice of the company. In addition, colleges and universities should strengthen and maintain their cooperative relationship with enterprises, and regard enterprises as an important base for colleges and universities to train compound marketing talents. Students improve their communication and practical skills through internships, and eventually become compound marketing talents that meet the needs of enterprises.

\subsection{Strengthen the Construction of "Dual-Teacher" Faculty}

The construction of the "dual-teacher" faculty team can be carried out from the following two aspects. On the one hand, college teachers need to go to the company for temporary training on the basis of acquiring a wealth of theoretical knowledge, so as to better integrate professional theoretical knowledge and practical ability. On the other hand, colleges and universities can introduce corporate executives or marketing talents with rich work experience to join the faculty to improve students' recognition and satisfaction with the school's faculty, thereby providing more learning materials and practical opportunities for marketing students to lay the foundation.

\section{CONCLUSIONS}

In the digital economy era, the traditional training model of marketing professionals has been unable to meet the needs of modern enterprises, so it is very important to innovate the training model of compound marketing talents. This paper mainly innovates from the aspects of repositioning the training target of compound talents, reconstructing the curriculum system, innovating the teaching mode, strengthening school-enterprise joint training and strengthening the construction of "double-qualified" faculty. The training model of marketing professionals in China is to improve students' big data thinking and practical ability, and cultivate more marketing professionals that meet the needs of enterprises. 


\section{ACKNOWLEDGMENT}

Collaborative Education Project of the Ministry of Education "Research on the training model innovation of compound talents in marketing in the digital economy era", Teaching Reform Project of Shandong University of Finance and Economics "Research on new retail talent training model innovation from the perspective of digital economy".

\section{REFERENCES}

[1] C.H. Xu, "Research on the training mode of marketing professionals based on the ability of digital marketing," The Guide of Science \& Education, 2020, PP. 60-61.

[2] L.J. Feng, "Exploration of Marketing Talent Training System from the Perspective of Digital Economy," Science \& Technology Economy Market, 2019, PP. 120-122.
[3] Q.W. Zhao and Q. Yang, The research of 'trinity' training mode on marketing inter-disciplinary talent: Marketing at Chongqing University as an example Modern Educational Technology, 2015, vol.25, pp.120-125.

[4] M. Zhang, "Discussion on the reform of marketing courses and teaching methods in the digital marketing era," Education Moderation, 2019, pp.45-51.

[5] L. Zhang and X.X. Li, "Research on the cultivation model of dig data marketing compound talents," China Management Informationization, 2020, vol.23, pp.207-209.

[6] B.W. Yu, "Research on improving the connection between marketing and market demand based on the new retail environment," Education Modernization, 2019, pp.105-107. 